\title{
DANSK EKSPEDITIONSFOND
}

[Summarized from information provided by Ebbe Munck and Commander (L) C. J. W. Simpson.]

During the Second World War,while Denmark was under German occupation, plans were being laid for three different expeditions, to start immediately the war had ended. As early as the summer of 1941, Dr A. F. Bruun and Hakon Mielche discussed plans for a future oceanographical expedition. Meanwhile, Ebbe Munck and Eigil Knuth were hoping to continue the work of the Danish North-East Greenland Expedition of 1938-40, and the late Henning HaslundChristensen was considering plans for an expedition to central Asia. The three groups had originally started preparations quite independently of each other, but in June 1945 their representatives held a conference and decided to co-operate in seeking financial support to supplement grants from the State and great national trusts. The initial draft proposals for a special fund for supporting expeditions were made at that time, and in the following two years the idea was rapidly developed.

The fund, known as Dansk Ekspeditionsfond, was officially established in May 1947 with the object of arousing the interest of all Danes, both at home and abroad, in the proposed expeditions. It was held that scientific research in the field would not only contribute to the benefit of Danish science, but also to the prestige of Danish initiative and enterprise. The governing board at present consists of the following members, all of whom serve in a purely honorary capacity: Vice-Admiral A. H. Vedel (Chairman), Hr. Holger Jensen (Treasurer), Hr. Leif Hendil (Secretary), Inspektor Ejnar Mikkelsen, Professor Knud Jessen, Professor Ragnar Spürck, Frk. Ingeborg Andersen, Dr Kaj Birket-Smith, and Hr. Ebbe Munck.

Money for the fund has been obtained in many different ways, the most usual procedure being for firms and individuals abroad to offer goods which are scarce (but not rationed) in Denmark. Thus in 1948 the income of the fund was almost entirely derived from the sale of cigarettes presented by Danes in the United States, the United Kingdom, and the Union of South Africa. By permission of Finansministeriet (the Danish Treasury), these were admitted to Denmark virtually free of customs duty. They were sold for a considerable profit owing to the acute shortage prevailing at the time. In 1949 a gift was received from $H$. Justesen, consisting of fresh pineapples which were flown from Rio de Janeiro to Denmark free of charge by Scandi. navian Airways System. The East Asiatic Company gave 20,000 coconuts which were sold without commission by a large store at $\mathrm{Kr} .3$ apiece. $\mathrm{Kr}$. 400,000 were received from the sale of beer, permission being given to brew a special consignment of pre-war strength for sale in aid of charities. A surplus stock of films was brought from Germany and sold for $\mathrm{Kr}$. 300,000. In many cases gifts were transported to Denmark free of charge by Danish firms. The system has the advantage that donors give only what is most easily available to them. Outright gifts of money have rarely been solicited or received.

Essential requirements for this kind of undertaking are first, that the 
chairman of the board be a figure of the highest national repute, and second, that no member of the board receive any form of remuneration.

A great deal is demanded of the secretary of the fund, who is mainly responsible for initiating each transaction. This involves not only canvassing for a gift of goods, but also approaching the requisite government department for remission of customs duty and finding a suitable wholesaler willing to distribute the goods free of charge.

In all these transactions the aim has been to interest the prospective buyer by offering for sale at a reasonable price some desirable article, of which there is a general scarcity. In other words, a little is collected from many, rather than much from few. No saleable object, not even a packet of chewing gum, is considered too humble for the benefit of this most worthy fund.

The income of the fund up to June 1951 amounted to about Kr. 3,000,000 and sums have been distributed as follows:

Danish Pearyland Expedition, 1948-51 . . . . . Kr. 1,200,000

Third Danish Expedition to Central Asia, 1948-50 . . . . Kr. 300,000

Oceanographical expedition in the Galatea . . . . . . . Kr. 1,000,000

Funds have also been supplied to Helge Larsen for archaeological investigations in Alaska, and to a Danish ethnographical expedition to central India.

This fine result is due to the goodwill shown by the Finansministeriet and other government offices, the press, business concerns and individuals, both at home and abroad.

\section{ICELANDIC GLACIOLOGICAL SOCIETY}

[Information supplied by Jon Eyporsson.]

Jöklarannsóknafélag Islands (the Icelandic Glaciological Society) was founded at Reykjavik on 22 November 1950 with the object of furthering glaciological investigations in Iceland. By May 1951 there were about 100 members, and a committee has been formed consisting of J. Eypórsson (President), G. Kjartansson (Secretary), S. Rist (Treasurer), T. Einarsson and A. Stefannson. The subscription rate for members is $\mathrm{Kr} .100 .00$ in the first year and $\mathrm{Kr} .25$ in each succeeding year.

Investigations began in the summer of 1951 at Esjufjöll on Vatnajökull, where a hut was established.

\section{THE ARCTIC AEROMEDICAL LABORATORY AT FAIRBANKS, ALASKA}

[Summarized from a paper by Captain Ernest L. McCollum, U.S.A.F., in "Proceedings of the Alaskan Science Conference of the National Academy of Sciences National Research Council. Washington, November 9-11." Bulletin of the National Research Council, No. 122, 1951, p. 171-74.]

The Arctic Aeromedical Laboratory was formed on 1 March 1947 at the United States Air Force School of Aviation Medicine, Randolph Air Force Base, Texas, and transferred in September that year to Ladd Air Force Base, 